continued to enjoy subsequently as a member of the senior XV of the Clontarf Rugby Club.

After 'house jobs' in Dublin and in hospitals in England and Wales, he began his psychiatric career as an assistant medical officer at Carlow District Mental Hospital, Eire, where he was greatly influenced by the then superintendent, Dr Green, whose progressive methods of psychiatric treatment were well known.

In 1962 Glass was appointed to a World Health Organization Fellowship and travelled in Finland, Holland and Switzerland, and was able to incorporate the best of their psychiatry in his subsequent treatment of patients.

He was appointed medical superintendent at St Davet's Hospital in 1948 and continued his distinguished career there until he retired in 1972. In 1935 he gained the DPM (Royal College of Physicians and Surgeons of Ireland), and in 1971 he was elected to the Foundation Fellowship of the Royal College of Psychiatrists.

He was predeceased by his wife, the former Murielle Slocock, and is survived by their son, Tim, his wife and their three children.

Henry Rollin

\section{John Daniel Sullivan \\ and John Dixon Richardson}

We would like to note the sad deaths of Dr John Daniel Sullivan, who passed away in January 2000, and Dr John Dixon Richardson, who passed away in April 2000.

\title{
miscellany
}

\section{Alois Alzheimer Award}

Novartis Pharma Germany sponsors the Alois Alzheimer Award (AAA) for outstanding achievements in the research of Alzheimer's disease and/or other neurodegenerative disorders. The research of the future award-winner should have led to new insights into the aetiology, pathology, diagnosis or treatment of Alzheimer's disease. The AAA is endowed with US\$20000 - applications or proposals for nominations (eight copies) should be directed to the Secretary of the Jury Board, Professor Dr H. J. Molle, Chairman of the University Hospital of Psychiatry, Nussbaumstrasse 7, 80336 Munich, Germany. Please include a short curriculum vitae and reprints of up to three relevant papers.

The deadline for applications/nominations is 31 December 2000. The Jury Board consists of: Professor K. Beyreuther, Heidelberg; Professor C. G.
Gottfries, Göteborg; Professor S. Henn, Mannheim; Professor R. Levey, London; Professor Dr J. M. Orgogozo, Bordeaux; Professor K. Maurer; Professor H. I. Moller; and Professor Dr B. Winblad, Huddinge.

\section{Self-help CD-ROM to tackle anxiety or depression}

Following successful field testing, the Mental Health Foundation has launched new self-help CD-ROM for anyone experiencing mild to moderate anxiety and/or depression. The CD-ROM, Restoring the Balance, is specifically designed to provide users with information and strategies for managing anxiety or depression. Although primarily designed for use in primary care settings, such as general practitioner surgeries where a practitioner is available to provide post-session support, this new program can also be used on its own by mental health service users. Its straightforward graphics make it particularly suitable for people who have little or no previous experience of using computers, and the CD-ROM comes complete with worksheets.

Restoring the Balance has been successfully field tested in a primary care setting with patients experiencing anxiety and depression. In comparison with a control group, use of the program by patients was found to have a positive impact on calmness and mood, measured on the Hospital Anxiety and Depression scale.

Restoring the Balance, price $\mathrm{f} 25$ for single user or $\mathrm{f} 85$ for multi-users is available from the Mental Health Foundation on tel: 0207535 7441/7455. For further information contact Lesley Warner, Mental Health Foundation, tel: 0207535 7422; e-mail: Lwarner@mhf.org.uk.

\section{forthcoming events}

The Forum on Learning Disability is holding a 1-day conference at the Royal Society of Medicine, London W1G OAE on Seven ages: transition and support in the lives of people with intellectual disabilities on Thursday 7 December 2000. The conference is concerned with the life span development of people suffering from learning disabilities and the importance of transitions from birth through to death. A number of eminent international speakers will be contributing to the day. For registration enquiries please contact Deborah Johns on tel: 0207290 2984; e-mail: deborah johns@ @oysocmed.ac.uk. This conference qualifies for five CME points. Registration fees: RSM Fellows, Forum members: £30.00; non-Fellows, non-Forum members: $\mathbf{6 0 0 . 0 0}$. Fee includes coffee, lunch and tea.
A 1-day conference, Serving the community: using health services research, will be administered by Mole Conferences for The Institute of Psychiatry, King's College London and the south London and Maudsley NHS Trust. The conference will be held at The Weston Education Centre, King's College London, in February 2001. For further information and booking forms please contact: Mole Conferences, 26 Church Road, Portslade, Brighton BN41 1LA; tel: 01273242 634; fax: 01273235 095; e-mail: enquiries@ mole-conference.com.

Professor R. N. Mohan, consultant in old age psychiatry and clinical tutor, Northern Birmingham Mental Health NHS Trust, is the organiser of two courses aimed at preparing trainees for the MRCPsych part II examinations. Critical review paper preparation course MRCPsych part II will be held on 24 and 25 January 2001 and MCQ/PMP course MRCPsych part II will be held on 14 and 15 February 2001 at the Birmingham Medical Institute. For further information contact Mrs Denise Makepeace, tel: 01216856574

Merton 2001 is running the Fifth workshop on evidence-based psychiatry at Merton College, Oxford, 4-6 April 2001. Evidence-based medicine provides a coherent approach to meeting the information needs of clinicians. Following a similar format to the four successful workshops at Merton College (19972000), this workshop will equip participants with the basic skills necessary to apply the principles of evidence-based medicine in psychiatry. 